\title{
Causes of late diagnosis of the reproductive organs' cancer in the opinion of suffering women from urban and rural areas of Lublin as an indicator of the condition of the early cancer detection system: a preliminary report
}

\author{
Renata Domżał-Drzewicka, Marianna Charzyńska-Gula, Zdzisława Szadowska-Szlachetka, \\ Agnieszka Bartoszek, Andrzej Stanisławek \\ Chair of Oncology and Environmental Health, Faculty of Nursing and Health Sciences, Medical University of Lublin, Poland
}

\begin{abstract}
Introduction: Tumours as well as the cardiovascular diseases are the leading causes of deaths in Poland. This article contains excerpts from research on complex causes of late diagnosis of cancer among the region's residents.

Aim of the study: One of the specific aims of the research undertaken was to learn about subjective assessment of women suffering from cancer taking into account its late diagnosis.

Material and methods: The research was conducted on 130 women with diagnosed cancer of reproductive organs in the late stage of the disease, who were in oncological care. The method of diagnostic survey in the form of a questionnaire was developed for the study.

Results: The research reveals that the place of living has an impact on the opinions of suffering women as for the causes of late diagnosis of cancer and, secondly, that their oncological awareness is low.

Conclusions:

1. In the examined group, cancer awareness of women already having cancers - irrespective of the environment of settling, was low and did not constitute the grounds for taking pro-health decisions in the area of the early diagnostic testing of cancer. This fully confirms the need for the research on effective tools to increase the awareness, particularly in the population of healthy persons, including menopausal and postmenopausal women.

2. The opinions indirectly indicate a weaker organization and effectiveness of the activities of the cancer prevention programs in the country than those organized in the city.
\end{abstract}

Key words: women, cancer, diagnosis, prevention.

\section{Introduction}

Tumours as well as cardiovascular diseases are the leading causes of deaths in Poland. This situation is due to the late detection and low treatment efficiency despite the continuous improvement of the situation [1]. Cancer incidence in Poland is terrifying. Currently, there are approximately 120,000 cancer cases per year and this number has been on increase for several years, the increase being faster than the population growth. These diseases are responsible for about $40 \%$ of deaths among women and approximately $30 \%$ of deaths among men aged 45-64 [2].

Since 2007, the number of reported cases of malignant cancer among women has been growing steadily. The standard incidence rates in 2010 were $254 / 10^{5}$ in men and $205 / 10^{5}$ in women. 365 out of 100 thousand people suffer from malignant cancer $[3,4]$.

Epidemiologists are analyzing the size and geographical distribution as for standardized rates of incidence and mortality due to cancer in Poland. Currently observed data follow the pattern which has been topical for more than three decades. On the top of the list of provinces according to the standardized rates of the incidence of cancer (ICD-10 C00-D-09) there are Pomorskie and Wielkopolska provinces. The Lublin region is in the middle of the list followed by the Podlasie, Mazowieckie and Opole provinces [4]. The analysis of the health situation of the Lublin region residents in recent years confirms that there exists a nationwide problem in attempts to combat cancer.

In the Lublin province in the same period (2010), there were more than 8 thousand cases of malignant 
cancer registered - 3,888 affected women. Compared with previous decades, this number of malignant cancer among women is increasing and approaching the number recorded for men in the same period. Men are more likely to die of cancer, but considering the population aged $40-44$ years, approximately $60 \%$ of deaths are among women [3-5].

In terms of the incidence of cancer among women in 2010 (as in the previous years), the Lublin province is dominated by breast cancers, gastrointestinal tract cancers, reproductive organs and lung cancers. In the case of cancer of the reproductive organs, uterine cancer ranks first $-7.2 \%$ of incidents $(n=278)$, followed by ovarian cancer $-5.7 \%$ of incidents $(n=222)$, and cervical cancer $-5.0 \%$ of incidents $(n=184)[3,4]$.

The standardized rate of the uterine body cancer has been constantly increasing. The rates increased from about 9/100 thousand in 1990 to more than $14 / 100$ thousand in 2010, which represents an about $80 \%$ increase. A less strong trend is observed for the ovarian cancer (from about 10/100 thousand in 1989 to almost $13 / 100$ thousand in 2010 , which represents a $25 \%$ increase). In 2010, one could observe a decrease in the standardized incidence rate of cancer of the cervix (from 13.2/100 thousand in 1989 and 13.0/100 thousand in 2008 to $8.2 / 100$ thousand in 2010), which may represent a misleading phenomenon considering the assessment of exposure to this cancer occurring in women living in the area of Lublin. At the same time, we can observe an increase in the number of registered cases of cancer in situ (D06) (66 cases in 2010; standardized incidence rate of 5.2/100 thousand females). Analyzing both invasive (C53) and non-invasive (D06) cervical cancer, the Lublin area would rank sixth for the most common cancers in women [3].

In total, there has been a slow downward trend in the country as for the incidence of deaths of this cancer, however, according to the National Cancer Registry data on mortality among Polish women, cervical cancer is still one of the major problems although the disease can be detected at an early stage [2, 3].

Taking everything into consideration, it can be concluded that the current epidemiological situation is a result of the unsolved problem of late diagnosis of cancer and a poor women's involvement in prevention activities. This condition persists despite the activities undertaken since 1996 by the National Health Program (NHP) - focused on one of the strategic objectives, including the fight against malignant cancer and the $\mathrm{Na}$ tional Programme for Combating Cancer [1-3].

In many states (Australia, the USA and member states of the "old" European Union) for the problem has been systematically reduced through general prevention campaigns on all levels of prevention and through the conducted research on individual patterns of behaviour in the area of health [6-9]; findings are be- ing used while drawing up promotional and preventive measures. Women in need of special care are the premenopausal, menopausal and postmenopausal ones.

To improve the effectiveness of cancer prevention, constant research on the pertinence, methodology and accuracy of preventive actions is required. This must be addressed to specific target groups functioning in different local communities. Such actions must consider the causes of late diagnosis of these diseases as well as insufficient health awareness and risk behavioural patterns of people that these actions concern.

\section{The aim of the study}

This study contains excerpts from research on the complex causes of late cancer diagnosis among Lublin region's residents. One of the specific objectives of the study was to learn the subjective opinion of women suffering from oncological problems about the causes of late diagnosis of cancer of their reproductive organs. An attempt was made to illustrate the problem of late cancer diagnosis and identify determinants of the problem, which seem to be important for the organizers of health care - mainly in the area of cancer prevention and early cancer diagnosis (screening).

\section{Material and methods}

The research group was constituted by 130 (100\%) women inhabiting the Lublin province, taking advantage of the cancer care, who had the malignant tumour of the reproductive organs diagnosed (cervical cancer or endometrial carcinoma) in the late phase of illness, during the last year from the date of the questionnaire survey. Sampling research had a character of the intentional selection.

The method of diagnostic survey in the form of a questionnaire was developed for the purpose of the research. Basic scientific research was preceded by a pilot study in which the hypothesis and research tools were verified. The research was a part of nursing diagnosis made by primary health care nurses working in the areas of residence of surveyed women. A permanent residence was the key variable included in the analysis of the causes of late cancer diagnosis.

The research was conducted in 2010-2012. The obtained testing material was analyzed by means of qualitative and statistical research with the use of software Statistica10.0 using nonparametric $\chi^{2}$ test. The $p \leq 0.05$ was assumed to be at the borderline level of statistical significance.

\section{Results}

One hundred and thirty (100\%) women took part in the study. The medium age of respondents was 55.14 
Tab. I. Characteristics of the study group in terms of place of residence

\begin{tabular}{lcc}
\hline Permanent residence & $n$ & $\%$ \\
\hline City & 68 & 52.3 \\
\hline Country & 62 & 47.7 \\
\hline Total & 130 & 100 \\
\hline
\end{tabular}

\pm 10.7 years (range: $26-86$ years). Menopausal or postmenopausal women prevailed, i.e. women at the age of $51-65(57.7 \%, n=75), 45-50$ years $(21.5 \%, n=28)$, above 65 years $(13.8 \%, n=18)$, but there were also women aged $31-45$ years $(3.8 \%, n=5)$ and up to 30 years of life $(3.1 \%, n=4)$.

Nearly half of the respondents were women with secondary education $(48.5 \%, n=63)$, higher education (25.3\%, $n=33)$, vocational education $(16.1 \%, n=21)$ and primary education $(10 \%, n=13)$. The distribution of respondents in terms of place of residence (city vs. country) is presented in Table I.

One should mention it that in 2010, according to data published by the Provincial Register of Cancer at

Tab. II. Causes of late cancer diagnosis in the opinion of the surveyed women

\begin{tabular}{|c|c|c|c|c|c|}
\hline \multirow[t]{2}{*}{ No. } & \multirow[t]{2}{*}{ Groups of causes } & \multicolumn{2}{|c|}{$\begin{array}{c}\text { City } \\
n=68\end{array}$} & \multicolumn{2}{|c|}{$\begin{array}{l}\text { Country } \\
n=62\end{array}$} \\
\hline & & $n$ & $\%$ & $n$ & $\%$ \\
\hline 1. & $\begin{array}{l}\text { Low level of knowledge } \\
\text { about the prevention of } \\
\text { cancer and distressing } \\
\text { symptoms }\end{array}$ & 65 & 95.6 & 51 & 82.2 \\
\hline 2. & Lack of risk awareness & 56 & 82.3 & 38 & 61.3 \\
\hline 3. & $\begin{array}{l}\text { Late detection of cancer } \\
\text { despite regular check-ups }\end{array}$ & 48 & 70.3 & 33 & 53.2 \\
\hline 4. & $\begin{array}{l}\text { Late gynaecologist ap- } \\
\text { pointment }\end{array}$ & 47 & 69.1 & 29 & 46.8 \\
\hline 5. & Fear of the diagnosis & 31 & 45.6 & 23 & 37.1 \\
\hline 6. & $\begin{array}{l}\text { Lack of interest in women } \\
\text { by other health practi- } \\
\text { tioners }\end{array}$ & 16 & 23.5 & 19 & 30.6 \\
\hline 7. & Financial problems & 9 & 13.2 & 19 & 30.6 \\
\hline 8. & $\begin{array}{l}\text { Difficulties in access to } \\
\text { medical specialists }\end{array}$ & 8 & 11.8 & 18 & 29.0 \\
\hline 9. & Sex of the gynaecologist & 7 & 10.3 & 13 & 21.0 \\
\hline 10. & $\begin{array}{l}\text { Impossibility to see a doc- } \\
\text { tor close to home }\end{array}$ & 5 & 7.3 & 11 & 17.7 \\
\hline 11. & $\begin{array}{l}\text { Lack of partner's consent } \\
\text { to visit a gynaecologist }\end{array}$ & 1 & 1.5 & 6 & 9.7 \\
\hline 12. & Lack of trust in the doctor & 0 & 0 & 6 & 9.7 \\
\hline 13. & Lack of free time & 0 & 0 & 4 & 6.4 \\
\hline 14. & Own negligence & 0 & 0 & 0 & 0 \\
\hline 15. & Fear of the examination & 0 & 0 & 0 & 0 \\
\hline
\end{tabular}

the St John from Dukla Centre of Oncology of the Lublin Province, in the Lublin province, altogether 413 cases of C-53 cancer $(n=134)$ and C-54 $(n=279)$ were registered. These women were predominantly aged over 40 years [4].

In the research, the percentage of working women $(31.5 \%, n=1)$ was similar to the one representing retired women $(28.4 \%, n=37)$ and pensioners $(33.8 \%$, $n=44)$. The smallest group was the one of the unemployed $(6.2 \%, n=8)$. More than half of women surveyed $(60 \%, n=78)$ were married. Cancerous diseases occurred in 56 families of the surveyed women (43.1\%). The most common malignant cancers among relatives of respondents were: cancer of the reproductive organs or cancer of the respiratory and gastrointestinal tract. The characteristics of women, in terms of their own health-related activities, clearly indicate that there exist deficits in this area among rural residents.

Almost two thirds $(65.4 \%, n=85)$ of respondents who are in the risk age group of developing reproductive organs' cancer (women aged over 25) said they did not receive any personal invitations to the preventive tests for cervical cancer. The majority of those women inhabit the rural areas.

Among women who received an invitation to take part in the preventive tests, 90\% $(n=40)$ participated in prevention programs. These were, in the great majority, urban residents (75\% of women who received an invitation to the preventive tests, $n=30$ ). $27.7 \%$ $(n=36)$ of women surveyed declared regular gynaecological examinations (at least once per year) - these are mainly inhabitants of the city, once every three years $-27.7 \%(n=36)$, and at least once every three years $45.4 \%(n=59)$ of women. $33.1 \%(n=43)$ of respondents perform breast self-examination once a month - more than half of them are city dwellers $(58 \%, n=25)$.

The potential causes of late cancer diagnosis among respondents were elaborated on the basis of the research indicating the common reasons for not reporting for cervical cancer screening tests [10-13]. The respondents could use a prepared list of the most common reasons for the late cancer diagnosis or make a list of their own reasons not included in the suggestions. Details of the collected opinions are shown in Table II.

Both country and city residents relatively frequently suggested four reasons for late cancer diagnosis (1 deficiencies or low levels of knowledge about the cancer prophylaxis and distressing symptoms, 2 - lack of awareness of cancer, 3 - late cancer detection by a doctor despite regular appointments, 4 - late gynaecologist appointment), other women stated the place of residence as the reason for late cancer detection ( $p \leq 0.05)$. Women living in the country, in the fifth and sixth place, (out of the total of 15 reasons) stated that the late diagnosis of cancer was due to the difficulties 
in access to a medical specialist (37.1\%, $n=23)$ and financial difficulties $(30.6 \%, n=19)$.

These reasons are mentioned as the eighth $(11.8 \%$, $n=8)$ and seventh (13.2\%, $n=9)$ ones, respectively, by respondents living in the city. As the fifth and sixth reasons for late cancer diagnosis, city residents mentioned fear of diagnosis $(45.6 \%, n=31$ ) and lack of interest of other physicians in their health $(23.5 \%$, $n=16)$. The country residents mentioned these causes as the eighth $(29.0 \%, n=18)$ and twelfth $(9.7 \%, n=6)$ ones, respectively.

Women living in the country also clearly indicate that the reason for their late diagnosis of cancer is the sex of a doctor $(30.6 \%, n=19)$. Moreover, their partners seem to be reluctant for the women to have a pelvic examination performed $(17.7 \%, n=11)$, and in the case of women living in the city $-10.3 \%, n=7$ and $1.5 \%$, $n=1$, respectively. The surveyed women rarely indicated self-negligence, fear of testing, lack of free time or lack of trust in the doctor as the reasons for late cancer diagnosis.

\section{Discussion}

In order to improve the effectiveness of cancer prevention, apart from the planned activities included in the National Programme for Combating Cancer, research on the effectiveness of prevention and causes of late diagnosis of cancer must be applied and carried out $[7,14,15]$. The analysis of the subjective opinion of oncological patients is undoubtedly one of the aspects of the research. In the literature we have never come across the subject presented in such a way. Despite this, the results obtained can be contrasted with reports of researchers dealing with the causes of low turnout of women in prophylaxis treatment, as well as inequalities in access to health care in rural and urban areas. The obtained results allowed us to identify the reasons for late cancer diagnosis among women in the rural areas. This may help identify the proper course of action to improve the effectiveness of cancer prevention.

On account of restrictions resulting from applying the intentional method of sampling, the study must be confirmed and supplemented on a research group appointed by way of random selection.

In the research, significant differences were stated in perceiving reasons for late diagnosing of the cancerous process between examined perimenopausal and postmenopausal women from the urban and rural environments.

Clear differences were noticed in the perception of the causes of late diagnosis of cancer among women from urban and rural environments. Such differences are also indirectly mentioned by other researchers involved in the analysis of the causes of low turnout of women in clinical prevention $[10,13,16,17]$.
Although it has been reported that the environment is important for the differences in the perception of reasons for late cancer diagnosis, extremely poor oncological awareness of the surveyed women is highly alarming. Let us remind that in the group of the four most frequently given reasons, three were associated with the awareness of women's health (deficiencies or low level of knowledge about the prevention of cancer, lack of cancer awareness, and late gynaecologist appointment).

They occurred despite the fact that $43.1 \%(n=56)$ of respondents confirmed that there was a person suffering from cancer in their family and is suffering mostly from the cancer of the reproductive organs. The results are fully confirmed in studies conducted by other researchers in the country and the world [7, 10, 11, 18].

It seems that the presence of a person suffering from cancer in the immediate family does not affect the growth of knowledge and may even contribute to giving up preventive measures because of the fear of the diagnosis. This was an important reason for late cancer diagnosis among respondents - these women were unfortunately suffering from cancer. The results indicate the need to focus on health education in terms of individual and social behaviour considering the environment.

Among the reasons for the late diagnosis of cancer, both women living the city and women living in the country often pointed out to the late detection of cancer by a doctor "despite regular visits" and - less frequently - to a lack of interest in their health presented by physicians. However, only women living in the country have mentioned "lack of confidence in the doctors" as the reason for late cancer detection.

These results indicate that gynaecologists and other specialists need to follow cancer prevention standards more strictly. Moreover, there should be an improvement in access to women gynaecologists in the rural areas. There are also numerous reports of researchers signalling the problem $[10,11,19]$.

According to the assumptions of the National Programme for Combating Cancer, a professional group of doctors is appointed to handle a difficult task to improve the health situation in the area of cancer diseases. It seems that without professional support of other professional groups which contribute to this area of health, the realization of this task will undoubtedly face a lot of difficulties. The research conducted in the USA among Hispanic women, residents of the U.S. and Mexico border area, show the benefits of introducing preventive measures other than medical education providers in the area of cancer prophylaxis [15] and thus confirm the need for the allocation of tasks in the area of prevention, diagnosis and oncological treatment compatible with the competence of specialists of the healthcare system $[11,20]$. 
A poor financial situation was given as the reason for late diagnosis of cancer by one third of the surveyed women living in the rural areas and about one sixth of surveyed women living in the city. Similar results were obtained by Marcinkowska in her research [19].

It is worth noticing that the "male partner's lack of consent to appointments with the gynaecologist" appears as the reason for late cancer diagnosis mainly among women living in rural areas. Such formulated reason may indicate indirectly to the large gaps as for knowledge on cancer prevention among partners of surveyed women [21, 22] but also on the disrupted process of interpersonal communication and cultural stereotypes deeply rooted in the environment of surveyed people.

Over $30 \%$ of women living in the country stated that the male gynaecologist and the impossibility to see a doctor close to their home were the significant causes of late diagnosis of cancer. The "male" sex of the gynaecologist contributed to postponing of the gynaecologist appointment for women living in the city but not to such an extent as in the case of women living in the country. This fact could be due to easier access to specialists of both sexes in urban areas than in rural areas. The "male" sex of the gynaecologist makes it difficult for women to participate in systematic, preventive, gynaecological studies as pointed out by other authors [23]. 33.1\% $(n=43)$ of respondents perform breast selfexamination once a month - more than half of them are residents of the city. In most analyzed reports, urban residents are more involved in health activities and preventive programmes than country residents. This fact is widely acknowledged and all the same should provide the basis for differentiation of planned activities in the area of cancer prevention in urban and rural areas [20, 24]. Analysis of subjective opinions of women about the reasons for the late cancer diagnosis is a valuable source of information about the social, individual, environmental and organizational causes of unsatisfactory impacts of cancer prevention and early diagnosis.

The analysis shows that the research on early detection of oncological problems is effective, provided that it is performed with appropriate frequency, which makes it possible to detect a disease in its early stages. Otherwise, the screening itself does not meet its goals, because the final success is connected with the conscious participation of women in the prevention of cancer. In Poland, the development of healthy social behaviour is not highlighted enough and this results in low health awareness [10, 20, 25]. It seems justified to state that programs to prevent cancer of the reproductive organs must take into account the specificity of physiological life spans of women, as the awareness of perimenopausal and postmenopausal women is still ruled by a conviction about the lack of need for systematic monitoring of the medical condition of reproductive organs.

\section{Conclusions}

1. The place of residence has an influence on opinions connected with the causes of late cancer diagnosis.

2. In the examined group, cancer awareness of women already having cancers - irrespective of the environment of settling, was low and did not constitute the grounds for taking pro-health decisions in the area of the early diagnostic testing of cancer. This fully confirms the need for the research on effective tools to increase the awareness, particularly in the population of healthy persons, including menopausal and postmenopausal women.

3. All gathered opinions indirectly indicate a weaker organization and effectiveness of actions of cancer prevention programs in the country rather than in the city. The data obtained confirm the need for further research concerning the complex causes of late cancer diagnosis taking into consideration the living environment, the availability of cancer health care in this environment, health awareness of its inhabitants and the use of professional educators who will strengthen the intellectual potential of the local community members and thereby increase the effectiveness of preventive measures.

\section{Disclosure}

Authors report no conflicts of interest.

\section{References}

1. Narodowy Program Zdrowia na lata 2007-2015 - Ministerstwo Zdrowia available at: www.mz.gov.pl/wwwfiles/ma.../docs/zal_urm_npz_90_150 52007p.pdf (access: 2013.11.30).

2. Narodowy Program Zwalczania Chorób Nowotworowych. Założenia i cele operacyjne 2006-2015; available at: http://www.mz.gov.pl/wwwfiles/ma_ struktura/docs/zalozenia ustawy o npzchn.pdf (access: 2013.11.30).

3. Kościelska B. Zachorowania i zgony z powodu nowotworów złośliwych w Regionie Lubelskim w 2010 roku. Centrum Onkologii Ziemi Lubelskiej im. św. Jana z Dukli. Wojewódzki Rejestr Nowotworów, Lublin 2013.

4. Wojciechowska U, Didkowska J, Zatoński W. Nowotwory złośliwe w Polsce w 2010 roku. Centrum Onkologii - Instytut im. M. SkłodowskiejCurie, Warszawa 2012

5. Ocena stanu zdrowia mieszkańców województwa lubelskiego. Urząd Marszałkowski Województwa Lubelskiego w Lublinie. Departament Zdrowia i Polityki Społecznej, Lublin 2010.

6. www.profilaktykarakaszyjkimacicy.pl (access: 2012.02.09)

7. Olesen SC, Butterworth P, Jacomb P, et al. Personal factor influence use of cervical cancerices: epidemiological survey and linked administrative data address the limitations of previous research. BMC Health Serv Res 2012; $12: 34$.

8. Kierunki rozwoju onkologii w Polsce: Programowa Narada Polskiego Towarzystwa Onkologicznego w dniu 04.04.2013; available at: www. pto.med.pl/aktualnosci/kierunki_rozwoju_onkologii_w_polsce_narada_pto_w_dniu_04_04_2013

9. Bojar I, Cvejić R, Głowacka DM, et al. Morbidity and mortality due to cervical cancer in Poland after introduction of the Act - National Programme for Control of Cancerous Diseases. Ann Agric Environ Med 2012; 19: 680-685.

10. Spaczyński M, Nowak-Markwitz E, Januszek-Michalecki L, et al. Profil socjalny kobiet a ich udział w Programie Profilaktyki i Wczesnego Wykrywania Raka Szyjki Macicy w Polsce. Ginekol Pol 2009; 80: 833-838. 
11. Bojar I, Wożnica I, Holecki T, et al. Dostępność badań cytologicznych oraz poziom wiedzy kobiet na temat ich znaczenia $w$ profilaktyce chorób nowotworowych narządu rodnego. Med Ogólna 2010; 16: 77-88.

12. Luszczynska A, Durawa AB, Scholz U, et al. Empowerment beliefs and intention to uptake cervical cancer screening: Tyree psychosocial mediating mechanisms. Women Health 2012; 52: 162-181.

13. Wożniak I. Wiedza o schorzeniach nowotworowych narządów kobiecych i postawy kobiet wobec badań profilaktycznych. Probl Pielęg 2008; 16: 136-143.

14. Spleen AM, Lengerich EJ, Camacho FT, et al. Health care avoidance among rural populations: results from a nationally representative survey. J Rural Health 2014; 30: 79-88.

15. Thompson B, Vilchis H, Moran C, et al. Increasing cervical cancer screening in the United States-Mexico border region. J Rural Health 2014; 30 196-205.

16. Bojar I, Biliński P, Boyle P, et al. Prevention of female reproductive system cancer among rural and urban Polish pregnant women. Ann Agric Environ Med 2011; 18: 183-188.

17. Pięta B, Wierzchowska-Chmaj K, Opala T. Life style and risk of develop ment of breast and ovarian cancer. Ann Agric Environ Med 2012; 19 379-384.

18. Black AT, McCulloch A, Martin RE, et al. Young women and cervical cancer screening: what barriers persist? Can J Nurs Res 2011; 43: 8-21.

19. Marcinkowska M, Mazurkiewicz P, Kozaka J, et al. Przyczyny niskiej frekwencji kobiet $w$ profilaktycznych badaniach mammograficznych. Psychoonkologia 2010; 2: 57-63.
20. Biała Księga. Zwalczanie raka jelita grubego i raka piersi w Polsce na tle wybranych krajów europejskich. Analiza zasobów systemu opieki onkologicznej i czynników warunkujących sukces. Ośrodek Analiz Uniwersyteckich Sp. z o.o., Warszawa-Kraków 2011 (access: 2013.11.21).

21. Pacewicz M, Krajewska-Kułak E, Krajewska-Ferishah K. Profilaktyka raka szyjki macicy - poziom wiedzy kobiet i mężczyzn. Med Paliat 2012; 4: 217-228.

22. Chmielarczyk W, Galicka M, Wojtaszczyk K. Refleksje na temat perspektywy edukacji onkologicznej w Polsce. Nowotwory Journal of Oncology 2011; 61: 178-180.

23. Wdowiak $A$, Bąk $M$, Lewicka $M$, et al. Opinie kobiet odnośnie przyczyn korzystania z porad lekarza ginekologa. Medycyna Ogólna i Nauki o Zdrowiu 2011; 17: 71-74.

24. Spleen AM, Lengerich EJ, Camacho FT, et al. Health care avoidance among rural populations: results from a nationally representative survey. J Rural Health 2014; 30: 79-88.

25. Cebulska V, Kożlak V, Rzempowska J, et al. Poziom wiedzy i umiejętności kobiet w wieku średnim w zakresie dokonywania samooceny zdrowia. Hygeia Public Health 2011; 46: 372-375.

26. Bakalczuk G, Wdowiak A, Lewicka M, et al. Evaluation of preventive screening cytology performed by menopausal women. Prz Menopauzalny 2012; 11: 129-134.

27. Tkaczuk-Włoch J, Sobstyl M, Jakiel G. Rak piersi - znaczenie profilaktyki pierwotnej i wtórnej. Prz Menopauzalny 2012; 11: 343-347. 